\title{
In Situ SE M Observation of Fracture Processes in Thin Film of Poly(methyl methacrylate) II. Stress Measurement
}

\author{
Tetsuya NISHIURA \\ Institute of Scientific and Industrial Research, Osaka University, 8-1 Mihogaoka, Ibaraki, Osaka 567-0047, Japan
}

(Received August 6, 2002; Accepted October 17, 2002)

\begin{abstract}
KEY WORDS In situ Observation / Scanning Electron Microscope (SEM) / Craze / Fracture / Poly(methyl methacrylate) (PMMA) / Stress Observation /
\end{abstract}

To investigate dynamic fracture processes of polymers on a microscopic scale, a fracture test of poly(methyl methacrylate) (PMMA) thin films was performed with scanning electron microscope (SEM) and fracture processes of the film were in situ observed. ${ }^{1}$ A crack is preceded by a craze. The mechanisms of propagation and fracture in the craze should be clarified. Test conditions affect nucleation of a craze, propagation of a craze and transformation to crack from the craze. Stress is an important factor in what yields a craze, and the relation between the stress and the craze behavior was studied. In bulk polymers, stress and stress intensity factors have been investigated. ${ }^{2,3}$ In thin polymer film, craze stress is measured indirectly using an optical density method. ${ }^{4}$ In previous work stress on the film subjected to tensile load was not detected. ${ }^{1}$

In this work, test equipment was improved to detect the tensile stress on the specimen. A small load cell was made from four strain gauges attached to a thin plate of stainless steel $(0.1 \mathrm{~mm} \times 8 \mathrm{~mm} \times 50 \mathrm{~mm})$. Bending strain of the plate was measured (Figure 1). The load cell was connected to a strain amplifier (Kyowa Electronic Instruments Co. Ltd. Japan, DPM-700B) by lead wires through the sample chamber of SEM.

Output signal of voltage was calibrated by standard weights. The calibration curve is shown in Figure 2. Output voltages $70 \mathrm{mV}$ and $143 \mathrm{mV}$ were gained for loads of $5 \mathrm{~g}$ and $10 \mathrm{~g}$, respectively. The relation between voltage and loads was almost linear and sensitivity was satisfied in this work.

PMMA samples (Comoglass, Kyowa gas Co. Ltd) with molecular weights (polystyrene standard) $M_{\mathrm{w}}$ and $M_{\mathrm{n}}$ were 139000 and 59900, respectively. Thin films of PMMA were produced by pulling a glass plate from the toluene solution of PMMA. ${ }^{1}$ The plate was kept in an oven at $65^{\circ} \mathrm{C}$ for $4 \mathrm{~h}$. Film thickness was $5 \mu \mathrm{m}$. Films on the glass plate were cut into rectan-

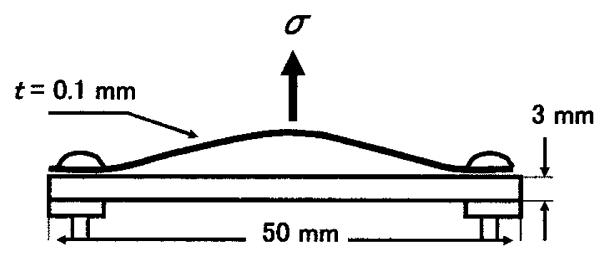

Figure 1. A load cell in tensile test machine.

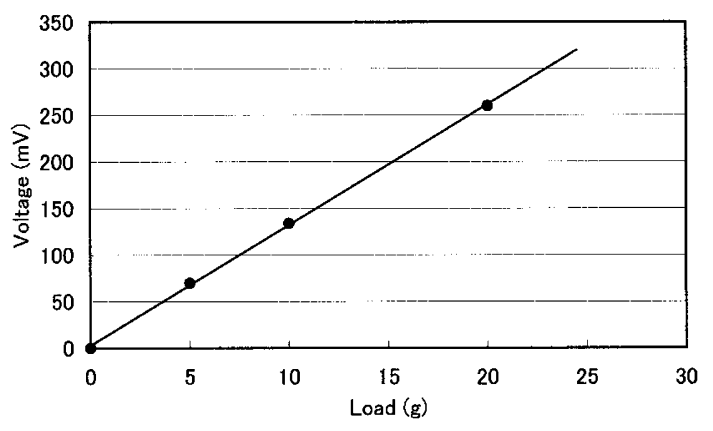

Figure 2. Calibration curve for output voltages $v s$. loads in a load cell.

gules $3 \mathrm{~mm} \times 10 \mathrm{~mm}$ and, then, immersed in a water bath. The rectangular films on water surface were dried in an oven at $65^{\circ} \mathrm{C}$ for $4 \mathrm{~h}$. A side edge on the films was notched by a razor. A single edge-notched specimen was fixed on chucks of the tensile test equipment. Tensile displacement speed was $1.2 \mathrm{~mm} \mathrm{~min}^{-1}$. Displacement was stopped intermittently to observe fracture processes and take photographs.

Photographs of extending cracks and crazes during tensile test are shown in Figures 3 and 4. Craze growth was of two types depending on the notch length. Type 1 is shown in Figure 3 and was generated from specimens with longer notches (notch length to specimen width, 0.567). Crazes show curved lines of white color and are observed in front of a crack at load of $1.64 \mathrm{~g}$ (Figure $3 b$ ). The increment of craze length is about $26.7 \mu \mathrm{m}$. At $11.64 \mathrm{~g}$ load (Figure 3c), crazes were 


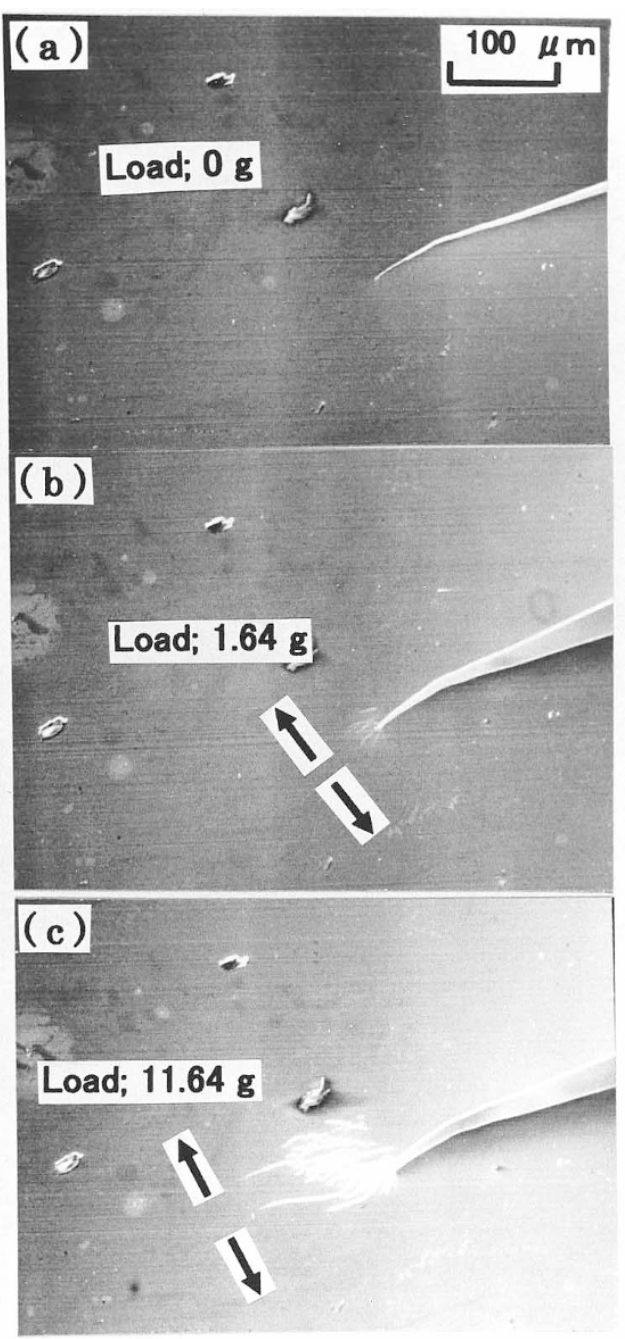

Figure 3. In situ SEM observation of fracture processes of thin film of PMMA. Thickness of the films, $5 \mu \mathrm{m}$. Notch length to the specimen width, 0.567. Arrows in photos show stress directions. The crazes grow smoothly with curved shape. These were type 1 crazes.

longer (increment of length, $80 \mu \mathrm{m}$ ) and thicker and increased in number. Cloud-like crazes are emerged around the big crazes. At last the specimen broke out at $14.2 \mathrm{~g}$.

Type 2 crazes were straight and few in number (Figure 4) and made from specimens with shorter notches (notch length to specimen width, 0.217). At $5.43 \mathrm{~g}$, craze increased and increment was $20 \mu \mathrm{m}$ (Figure $4 \mathrm{~b}$ ) and at $9.5 \mathrm{~g}$ craze increment was $38.4 \mu \mathrm{m}$ (Figure $4 \mathrm{c}$ ). At $12.86 \mathrm{~g}$ the specimen broke out.

For a single edge notched specimen, stress concentrates at the edge of notch and stress concentration factor increases due to crack nucleation at the edges. In bulk specimens, to account the stress around the crack stress intensity factor is normally used. Stress intensity factors were thus calculated from loads, crack length, and thicknesses. In this work, crack length was total length of crack and craze. Stress intensity factor was

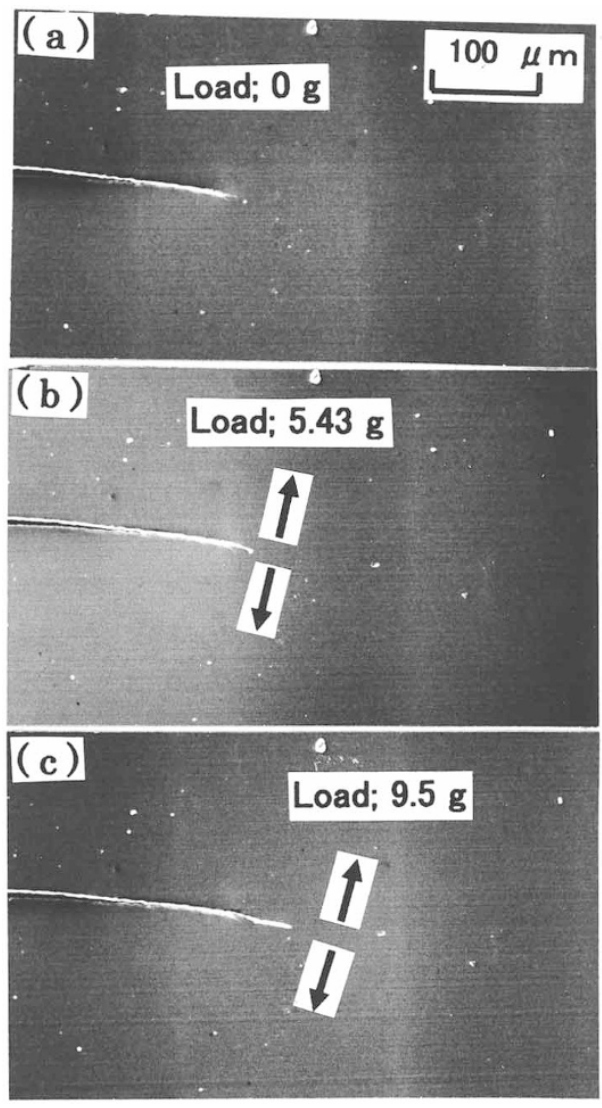

Figure 4. In situ SEM observation of fracture processes of thin film of PMMA. Thickness of the films, $5 \mu \mathrm{m}$. Notch length to specimen width, 0.217. Arrows in photos show stress directions. The crazes were straight and crack-like in shape. These were type 2 crazes.

an apparent value because the true crack length was not used. The stress intensity factor $(K)$ was calculated as,

$$
\begin{aligned}
& K=F(a / W) \sigma \sqrt{(\pi a)} ; \quad a / W=\xi \\
& F(\xi) \fallingdotseq 1.12-0.231 \xi+10.55 \xi^{2-} 21.72 \xi^{3}+30.39 \xi^{4}
\end{aligned}
$$
where $a, W$, and $\sigma$ are crack length, specimen width and stress, respectively.

The apparent stress intensity factors $(K)$ of the type 1 are $0.32 \mathrm{MNm}^{-3 / 2}, 2.46 \mathrm{MNm}^{-3 / 2}$, and $3.50 \mathrm{MNm}^{-3 / 2}$, respectively, for loads of $1.6 \mathrm{~g}, 11.6 \mathrm{~g}$, and $14.2 \mathrm{~g}$ (Figure 3 ). Stress intensity factors of type 2 were $0.24 \mathrm{MNm}^{-3 / 2}, 0.43 \mathrm{MNm}^{-3 / 2}$, and $0.62 \mathrm{MNm}^{-3 / 2}$, respectively, for loads of $5.43 \mathrm{~g}, 9.5 \mathrm{~g}$, and $12.86 \mathrm{~g}$ (Figure 4). $K$ s for type 1 were larger than $K$ s for type $2 . K$ of type 1 at fracture $\left(K_{\mathrm{c}}\right)$ was much larger than $K_{\mathrm{c}}$ of type 2. This relation between craze figure and strength is similar to the relation in wet craze. ${ }^{6}$ For mild crazeinducing-agents, curved craze grew smoothly to produce multiple crazes. Fractures occurred at higher load. Type 1 crazes thus resemble those with mild agents. With severe craze-inducing-agents sharp straight crazes grew stepwise. Fractures occurred at lower loads. Type 2 crazes resemble those with severe agents. The conditions for craze formation were found to resemble to wet 
craze conditions, although the crazing agents were not used.

Loads in the tensile test of PMMA thin films could to be measured by SEM in situ observation. The two types of craze nucleation and propagation were found. $K_{\mathrm{c}}$ in type 1 craze was higher than with $K_{\mathrm{c}}$ in type 2 . To clarify the reason for this, different test conditions will be studied in the future.

\section{REFERENCES}

1. T. Nishiura and S. Nishijima, Polym. J., 33, 819 (2001).
2. K. Kendall, W. J. Clegg, and R. D. Gregory, J. Mater. Sci. Lett., 10, 671 (1991).

3. E. J. Kramer and E. W. Hart, Polymer, 25, 1667 (1984).

4. B. D. Lauterwasser and E. J. Kramer, Philoso. Magazine A, 39, 469 (1979).

5. H. Tada, P. C. Paris, and G. R. Irwin, "The Stress Analysis of Cracks Handbook", Del Research Corporation, Hellertown, Pennsylvania, P. A. 1973, 2.10.

6. T. Nishiura, T. Joh, S. Okuda, and M. Miki, Polym. J., 13, 611 (1981). 